\title{
Characterization of the early development of Pseudoplatystoma reticulatum Eigenmann \& Eigenmann, 1889 (Siluriformes: Pimelodidae) from the Paraguay River Basin
}

\author{
Fernanda F. Andrade ${ }^{1}$, Ariane F. Lima ${ }^{1}$, Lucileine Assumpção ${ }^{1}$, Sergio Makrakis ${ }^{1}$, \\ Rodrigo I. D. Kasai ${ }^{2}$, and Maristela C. Makrakis ${ }^{1}$
}

\begin{abstract}
This study described the initial development of Pseudoplatystoma reticulatum, as well as changes in growth patterns. Morphometric and meristic variables were analyzed during embryonic, larval and juvenile periods, even as allometric growth coefficients for larvae and juveniles. Eggs showed an average diameter of $1.79 \mathrm{~mm}$ and broad perivitelline space (23.41\%). The total length (TL) of the larvae ranged from 3.05 to $25.72 \mathrm{~mm}$, and the total number of myomeres ranged from 45 to 50 (preanal $=13-16$ and postanal $=30-35$ ). Initial pigmentation is poor, concentrated at the extremities of the yolk sac. In the flexion stage, the pigmentation intensifies and forms a longitudinal stripe extending from the snout to the operculum and two longitudinal stripes on the body, one dorsal and the other ventral, that unite at the caudal peduncle. At first, there is a differential growth of the head and tail, and then there is the growth of the body, which shows changes in the ontogenetic priorities of feeding, swimming, and breathing capacities. Our results are very important for ecology, systematics, and hatchering, especially in terms of ontogenetic variation in morphology, growth, feeding, behavior, and mortality of $P$. reticulatum.

Este estudo descreveu o desenvolvimento inicial de Pseudoplatystoma reticulatum, bem como as mudanças nos padrões de crescimento, testando a hipótese da ocorrência de crescimento diferencial durante a ontogenia inicial da espécie. Variáveis morfométricas e merísticas foram analisadas durante os períodos embrionário, larval e juvenil, assim como os coeficientes de crescimento alométrico para larvas e juvenis. Os ovos apresentaram diâmetro médio de $1,79 \mathrm{~mm}$ e espaço perivitelino amplo (23,41\%). O comprimento total (CT) das larvas variou de 3,05 a $125,72 \mathrm{~mm}$ e o número total de miômeros de 45 a 50 (pré-anal=13-16 e pós-anal=30-35). A pigmentação inicial é escassa, concentrada nas extremidades do saco vitelino. A partir do estágio de flexão a pigmentação se intensifica, formando uma faixa longitudinal que se estende do focinho ao opérculo e duas no corpo, uma dorsal e outra ventral, que se unem no pedúnculo caudal. Inicialmente há um crescimento diferenciado da cabeça e da cauda, com posterior crescimento do tronco, que demonstra mudanças nas prioridades ontogenéticas para as capacidades de alimentação, natação e respiração. Nossos resultados são de grande importância para a ecologia, sistemática e larvicultura, especialmente em termos de variação ontogenética na morfologia, crescimento, alimentação, comportamento e mortalidade P. reticulatum.
\end{abstract}

Keywords: Allometric growth, Early life stages, Fish larvae, Morphology, Ontogeny.

\section{Introduction}

Pseudoplatystoma reticulatum, locally known as "cachara", "surubim" and "surubim-cachara", is a piscivorous fish of nocturnal habits (Resende et al., 1996). It is a large-sized species, with gray color and body covered with vertical stripes that may be dorsally bordered in the front and back by small stripes, and fins with back spots
(Castro, 1986). This species undergoes reproductive migration; it reproduces in the riverbed during the rainy season, with total spawning mainly from December to February (Resende et al., 1995). According to Romagosa et al. (2004), when P. reticulatum is kept in captivity, it shows physiological reproductive particularities and does not complete its reproductive cycle. This process occurs due to the lack of stimuli coming from the migration process.

\footnotetext{
${ }^{1}$ Pós-Graduação em Recursos Pesqueiros e Engenharia de Pesca, Universidade Estadual do Oeste do Paraná - UNIOESTE, Grupo de Pesquisa em Tecnologia em Ecohidráulica e Conservação de Recursos Pesqueiros e Hídricos - GETECH, Rua da Faculdade, 645, 85903-000 Toledo, PR, Brazil. (FFA) ferfandrade@gmail.com (corresponding author), (AFL) ariane.f.1@hotmail.com, (LA)duaslu@hotmail.com, (SM)makrakis@terra.com.br, (MCM)mmakrakis@terra.com.br

${ }^{2}$ Piraí Piscicultura, BR 262 - Km 424, Fazenda Cachoeirão GVIII, Terenos, MS, Brazil. rodrigokasai@hotmail.com
} 
Therefore, techniques are needed to trigger spawning (Benitez et al., 2003; Romagosa et al., 2004; Leonardo et al., 2004). Hence, studies on growth and development of $P$. reticulatum in captivity are crucial for improving the reproductive success of this species. Those studies may allow a better understanding of the economic potential of this species and its environmental implications.

In Brazil, P. reticulatum is among the freshwater fish with highest commercial value (Crepaldi et al., 2008). Besides being appreciated in sport fishing due to its strength and size (Reid, 1983), P. reticulatum has favorable characteristics for large-scale breeding, such as light-colored meat, mild taste, low-fat content, firm texture, and few intramuscular spines (Romagosa, 2006). Due to the high price of its meat, it has suffered from predatory fishing. Moreover, environmental changes, such as pollution, river damming, improper use of pesticides, and drainage of marginal lagoons, have reduced the natural stocks of $P$. reticulatum over the years, so this fish is becoming scarce in La Plata River (Resende, 2003).

Several studies have been carried out to elucidate aspects of the reproductive biology of $P$. reticulatum in captivity and its induced reproduction (Romagosa et al., 2004, 2005; Leonardo et al., 2004; Romagosa, 2006, 2010, and Streit Júnior et al., 2012). However, information on its early development stages remains scarce, with some aspects of embryonic and larval development of the species described by Kossowski \& Madrid (1991).

The ability to produce a complete series of the early development of $P$. reticulatum provides an opportunity to advance the knowledge of the species, which is fundamental to set the ground for its management and conservation, as well as for larviculture. Considering the high fishing and biotechnological importance of $P$. reticulatum, the present study aimed to describe the embryonic, larval, and juvenile development of the species, through morphometric and meristic variables and pigmentation pattern. We also tested the occurrence of differential growth of body parts during the early development to provide subsidies for the identification of the species collected in its natural environment.

\section{Material and Methods}

Eggs, larvae, and juveniles of $P$. reticulatum were obtained through induced reproduction using breeders from the Paraguay River Basin (Aquidauana, Miranda, and Paraguay rivers). We carried out sampling from January to February 2012 at Piraí Pisciculture in Terenos, Mato Grosso do Sul State, mid-western Brazil.

Spawning was induced by injection of a dose of $5.0 \mathrm{mg}$ $\mathrm{kg}^{1}$ of carp pituitary extract. After fertilization, the eggs in 100-L funnel incubators, and an open water system provided water flow. The periodicity in the obtainment of samples varied according to the development degree. The eggs were collected after hydration with 2 -h intervals until hatching. After hatching, larvae were collected at every 12 $\mathrm{h}$, during seven days. From the $8^{\text {th }}$ day on, we carried out sampling at every $24 \mathrm{~h}$ (once a day) for seven days. After this period, larvae were collected at every $48 \mathrm{~h}$ (at every two days), until they became juveniles.

The larvae were initially fed (two days after hatching) using newly-hatched Artemia. After ten days, the larvae started the process of food conditioning. At this stage, we used a commercial ration of $56 \%$ (crude protein), bovine heart, and some nutritional additives. This process consists in the replacement of meat with ration of $20 \%, 40 \%, 60 \%$, $80 \%$, and transition to $100 \%$ of extruded ration. The mean water temperature was $27.5^{\circ} \mathrm{C}$ during the larviculture and initial juvenile period.

Samples were previously submitted to eugenol solution (clove oil $-0.5 \mathrm{ml}^{1 \mathrm{l}^{-1}}$ ), fixed in $4 \%$ formalin, and placed in glass flasks. The eggs were classified in the following development stages, according to Nakatani et al. (2001) with modifications: (a) morula; (b) gastrula; (c) initial embryo - stage when the differentiation of the embryo occurs; (d) formation of the tail; (e) free tail - stage when the tail detaches from the yolk; (f) final embryo - stage when the embryo is nearly formed.

Larval classification into different stages followed Ahlstrom \& Ball (1954) modified by Nakatani et al. (2001): (a) yolk-sac larva, (b) preflexion larva, (c) flexion larva, and (d) postflexion larva; and juveniles - fish considered small adults, with complete formation of the fin rays, until the first sexual maturation.

For the characterization of the early development of the species, morphometric measurements (expressed in millimeters) from digital photographs obtained with a digital camera (OLYMPUS, model DP-25) coupled to a stereoscopic microscope (OLYMPUS, model SZX7), using the software DP2-BSW for the analysis of digital images.

The variables total diameter (EGD), yolk-sac diameter (YSD), and perivitelline space (PS) were obtained from eggs (Fig. 1a) (EGD from morula stage; YSD and PS in the morula and gastrula stages); the perivitelline space was characterized according to its participation in the total volume of the egg (Nakatani et al., 2001). The morphometric variables obtained from larvae and initial juveniles were: total length (TL), standard length (SL), snout length (SNL), eye diameter (ED), head length (HL), trunk length (TRL), tail length (TAL), head height (HH), body height at the level of the pectoral fin $(\mathrm{BH})$, body height at the level of the anus (BHa), caudal peduncle height $(\mathrm{CPH})$, pre pectoral-fin length (PPD), pre pelvic-fin length (PPvD), pre dorsal-fin length (PDD), and preanal-fin length (PAD) (Fig. 1b-c). The meristic variables comprised the total number of myomeres, number of preanal myomeres (NPAM), number of postanal myomeres (NPSM), number of rays of the pectoral fin (NRPF), number of rays of the pelvic fin $(\mathrm{NRPvF})$, number of rays of the dorsal fin (NRDF), and number of rays of the anal fin (NRAF). 
a

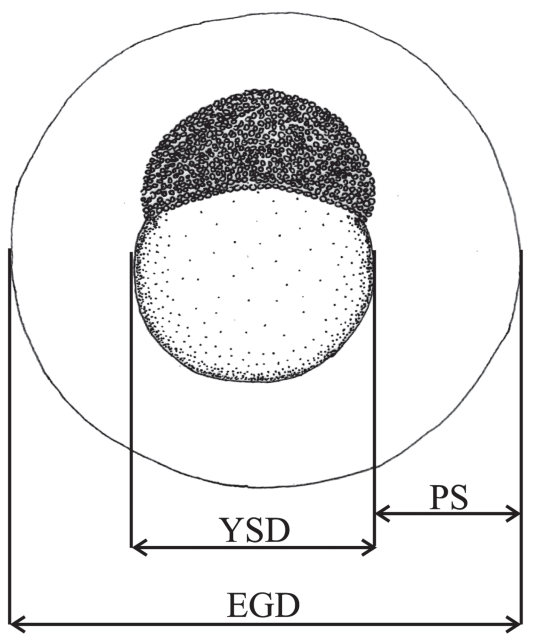

b

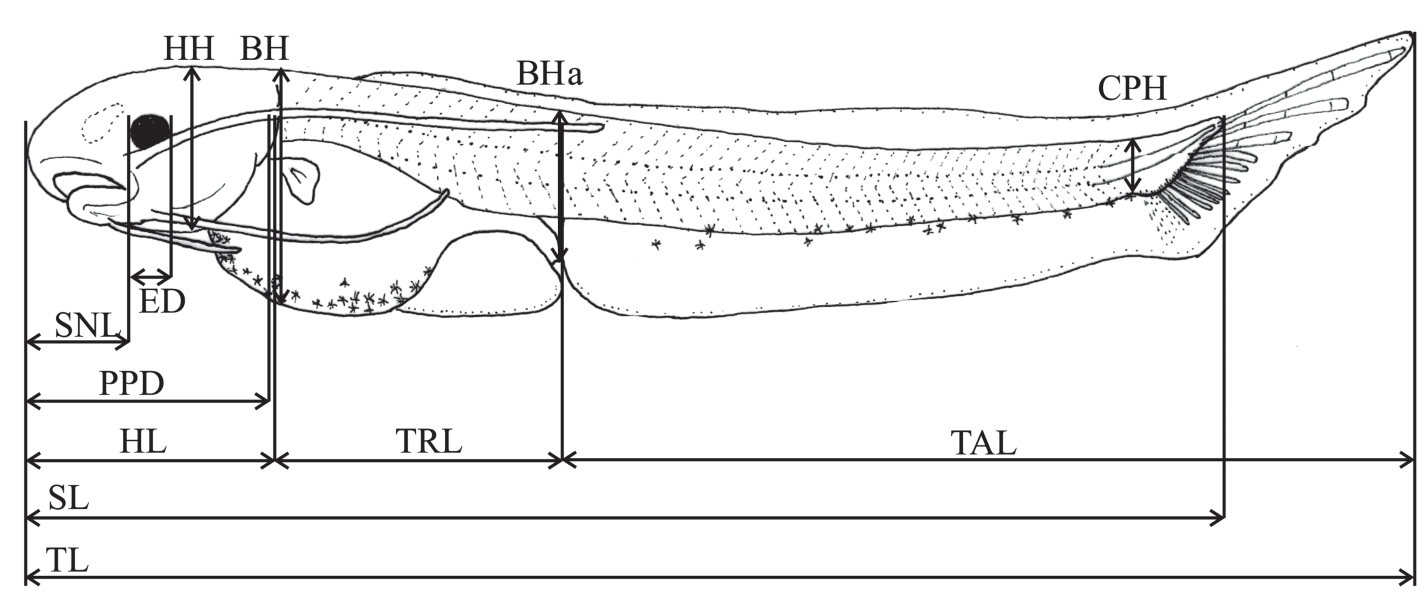

c

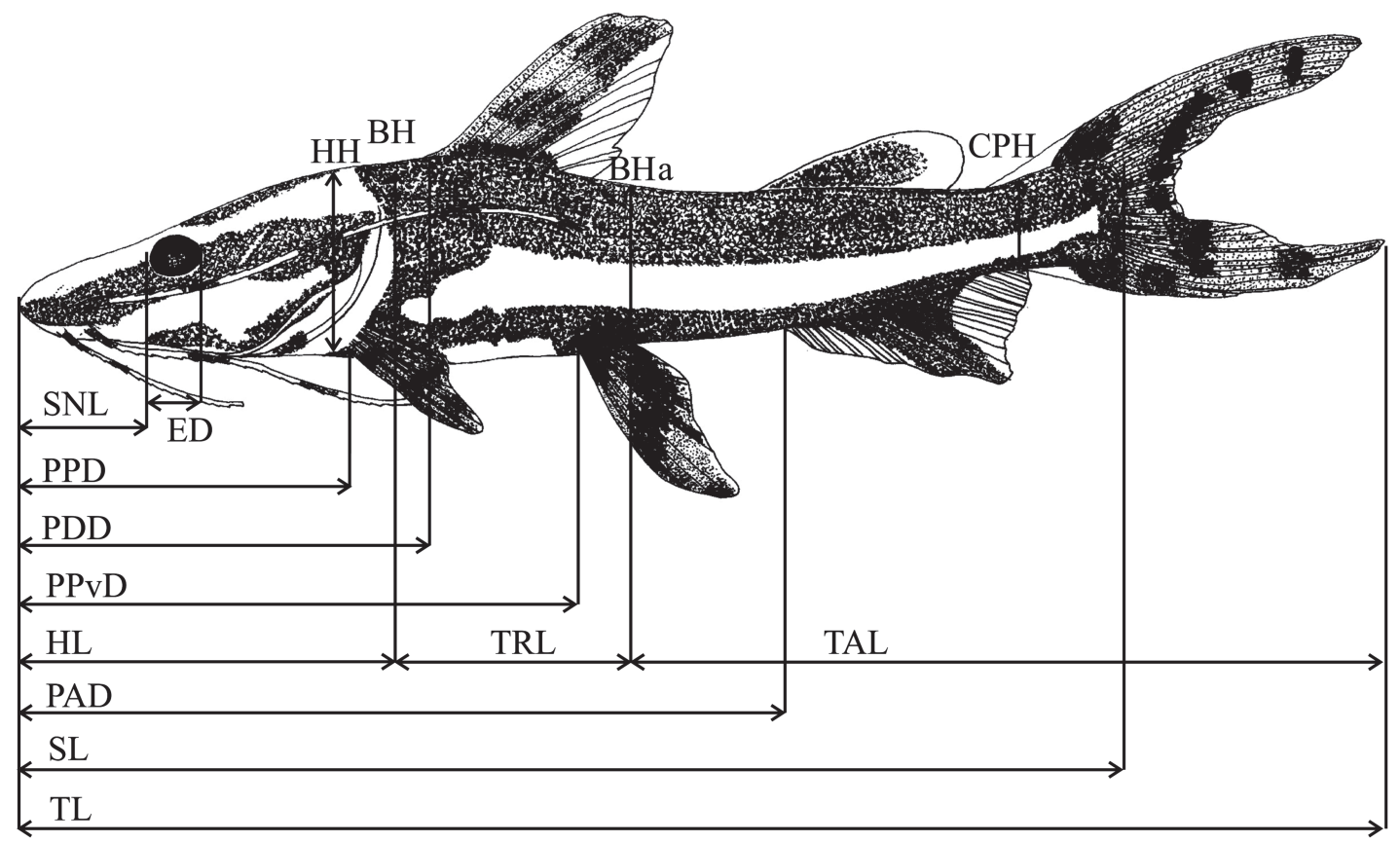

Fig. 1. Schematic diagram of the measurements taken: (a) eggs, (b) larvae, and (c) juveniles of Pseudoplatystoma reticulatum. EGD: total diameter, YSD: yolk-sac diameter, PS: perivitelline space, TL: total length, SL: standard length, SNL: snout length, ED: eye diameter, HL: head length, TRL: trunk length, TAL: tail length, HH: head height, BH: body height at the level of the pectoral fin, BHa: body height at the level of the anus, CPH: caudal peduncle height, PPD: pre pectoral-fin length, PPvD: pre pelvic-fin length, PDD: pre dorsal-fin length, and PAD: pre anal-fin length. 
In yolk-sac larva, the maximum and minimum diameter of the ellipsoidal yolk sac was also measured and calculated the volume $\left(\mathrm{mm}^{3}\right)$ using the formula: $\mathrm{V}=$ $0.1667 \pi \mathrm{Dd}^{2}$, where $\mathbf{V}$ is the volume, 0.1667 is a constant, $\pi$ corresponds to 3.14159 , $\mathbf{D}$ is the maximum diameter, and $\mathbf{d}$ is the minimum diameter of the yolk sac (Heming \& Buddington, 1988). All measurements were taken along parallel or perpendicular lines to the horizontal axis of the body (Gisbert, 1999).

In addition to the description of each stage based on the development degree, the occurrence of the main morphological events was also observed and photographed and illustrated the individuals that best represented these characteristics using a digital camera and camera lucida, respectively, coupled to a stereoscopic microscope. Individuals used in this research have been deposited in the Ichthyological Collection of the Núcleo de Pesquisas em Limnologia, Ictiologia e Aquicultura (Nupélia) at the Universidade Estadual de Maringá (UEM), Paraná, Brazil (NUP 17329).

To test for differential growth during early development, the larvae and juvenile were weighted on an analytical balance (0.00001 g, Model AW220 SHIMADZU). Linear regressions were made with $\log$ (x)-transformed data. As there was no linear relationship between total length and age, as well as weight and age, the exponential model $\left(y=a^{b x}\right)$ was applied, using the values of $\mathbf{a}$ and $\mathbf{b}$ from the linear regression calculated in the previous step. To test for growth changes in specific body parts, the morphometric variables (dependent variables) were plotted against the total length (TL) (explanatory variable), and analyzed their relationships using several regression models (Kováč et al., 1999). The dependent variables used were body height at the level of the pectoral fin (BH), head height $(\mathrm{HH})$, eye diameter (ED), body height at the level of the anus $(\mathrm{BHa})$, and caudal peduncle height $(\mathrm{CPH})$ (Peña \& Dumas, 2009). First, we tested the hypothesis that body ratio development is continuously isometric using a simple linear regression model. Besides, we also tested two alternative hypotheses: gradual allometric growth by using a quadratic regression analysis and discontinuous isometric growth by using a piecewise linear regression analysis, which is characterized by breakpoints reflecting divergent growth rates (Lopes et al., 2015). The optimal models for each morphometric variable relative to body size using F tests (Sokal \& Rohlf, 1981). The significance level for the analyses was $\mathrm{p}<0.05$.

The coefficient of growth for the head, trunk, and tail in relation to total length was also used to visualize changes during growth and development at successive stages. For the analyses of allometric growth patterns, linear regressions of $\log (\mathrm{x})$-transformed data were calculated to obtain $b$ value (coefficient of growth) extracted from the equation $\mathrm{y}=\mathrm{a}+\mathrm{bx}$, where $\mathbf{y}$ is the dependent variable (body parts measurements), $\mathbf{x}$ is the independent variable (total length), $\mathbf{a}$ is the intercept and $\mathbf{b}$ is the coefficient of growth
(Peña \& Dumas, 2009). The allometry and isometry patterns were described for all development stages, according to the values of growth coefficient obtained, i.e., if $\mathrm{b}<1$, the allometric growth is negative; if $\mathrm{b}>1$, the allometric growth is positive; and if $b=1$, the growth is isometric (Peña \& Dumas, 2009).

\section{Results}

Embryonic period. The duration of the embryonic period (incubation - from fertilization to hatching) lasted $14 \mathrm{~h}$ under an average temperature of $28.2^{\circ} \mathrm{C}$ (Fig. 2a).

A total of 70 eggs of $P$. reticulatum was analyzed (Table 1). They are spherical, transparent, and nonadhesive (Fig. 3a-f). The membrane of the egg is unique without gelatinous layer, and the color of the yolk is yellow. The average diameter of the egg was $1.79 \pm 0.14 \mathrm{~mm}$ ( \pm standard deviation), the average diameter of the yolk sac was $0.84 \pm 0.07 \mathrm{~mm}$, and the perivitelline space was broad (23.41\%), with an average size of $0.41 \pm 0.06 \mathrm{~mm}$. The morula stage (Fig. 3a) was observed $2 \mathrm{~h}$ after fecundation. Gastrulation began $4 \mathrm{~h}$ after fecundation (Fig. 3b), embryo differentiation began $6 \mathrm{~h}$ after fecundation (Fig. 3c), and the tail extremity detached itself approximately $10 \mathrm{~h}$ after fecundation (Fig. 3e). The last stage corresponds to the final embryo (Fig. 3f).

Larval period. Fourteen hours after fertilization and incubation, the larvae hatched at an average temperature of $28.2{ }^{\circ} \mathrm{C}$ (Fig. 2b). A total of 220 larvae was analyzed, with a total length ranging from 3.05 to $25.72 \mathrm{~mm}$ (Table 1).

Yolk-sac larva (Fig. 4a): the larvae hatched with a total length that ranged from 3.05 to $3.23 \mathrm{~mm}$ (mean $\pm \mathrm{SD}=$ $3.13 \pm 0.05 \mathrm{~mm}$ ) and showed a relatively large elliptical yolk sac, with a volume that ranged from 0.28 to 0.37 $\mathrm{mm}^{3}$ (mean $\pm \mathrm{SD}=0.32 \pm 0.03 \mathrm{~mm}^{3}$ ). The pigmentation is poor, restricted to only a few chromatophores in the ventral region of the body and concentrated at the anterior and posterior extremities of the yolk sac. The eye has no pigmentation and is not evident. The embryonic fin, the finfold, begins at the posterior extremity of the yolk sac, surrounds the caudal peduncle and goes on dorsally towards the head up to the yolk sac level. Myomeres are difficult to visualize.

Preflexion (Fig. 4b): approximately $12 \mathrm{~h}$ after hatching, the total length of the larvae ranged from 3.83 to 4.01 $\mathrm{mm}$ (mean $\pm \mathrm{SD}=3.95 \pm 0.05 \mathrm{~mm}$ ). The pigmentation is maintained, the maxillary barbels begin to develop. The eye is more evident, but it still is poorly pigmented. The total number of myomeres varied from 48 to 50 (preanal $=$ 14-15 and postanal $=33-35)$.

Flexion (Fig. 4c-e): this stage began approximately 24 $\mathrm{h}$ after hatching, and in it the total length ranged from 4.32 to $10.17 \mathrm{~mm}$ (mean $\pm \mathrm{SD}=7.33 \pm 1.67 \mathrm{~mm}$ ). There was an increase in the number of chromatophores; they are distributed all over the ventral region of the yolk 
sac, which already has a much reduced size. The bud of the pectoral fin appears, the eye is well pigmented, the mouth formed and the anus is completely open (transition from the endogenous to the exogenous feeding). The operculum is well formed, one pair of maxillary barbels and two pairs of mentonian barbels are present. There is also the notochord flexion and formation of rays in the caudal fin. At the end of this stage, the yolk sac is completely absorbed, the dorsal fin begins to be formed, and there are chromatophores and pigmentation on the upper region of the swimming bladder, forming a longitudinal stripe on the lateral side of the head. The number of myomeres ranged from 45 to 50 (preanal $=$ 13-16 and postanal $=30-35$ ).

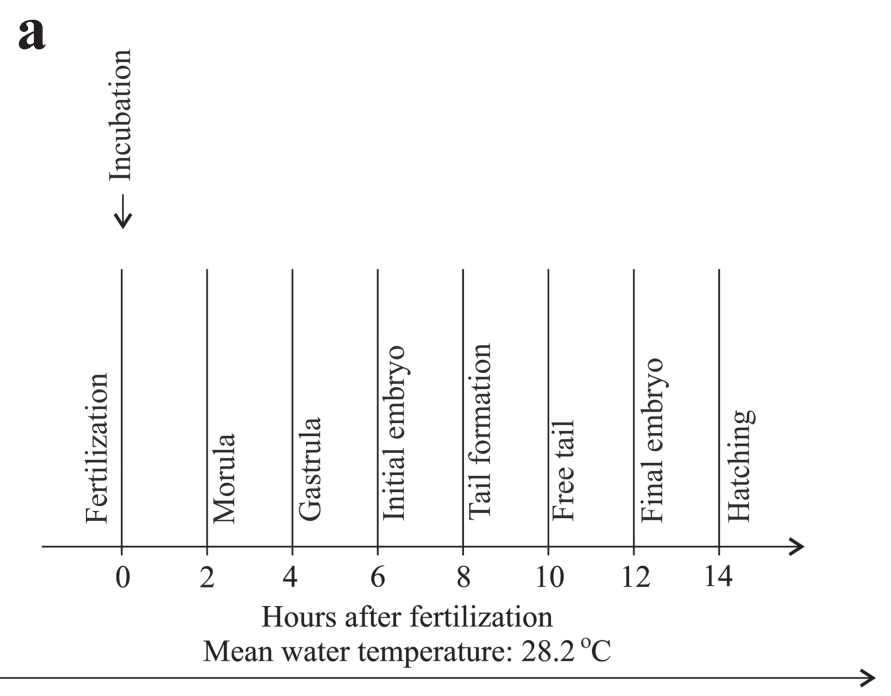

Embryonic Development

\section{b}

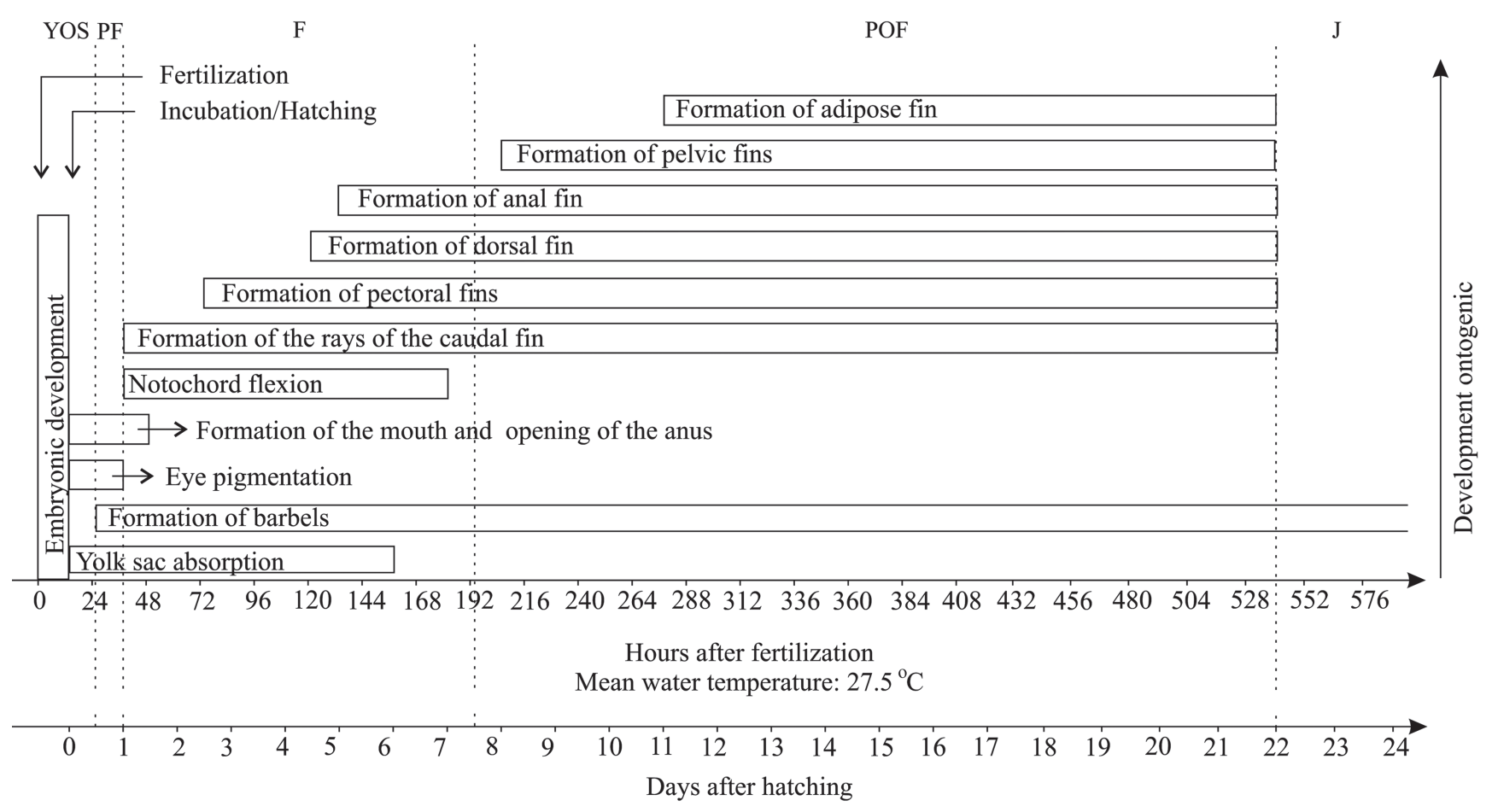

Fig. 2. Morphological events observed during the development of Pseudoplatystoma reticulatum, in the (a) embryonic, (b) larval and juvenile period. YOS: yolk-sac larva, PF: preflexion, FL: flexion, POF: postflexion, and J: juvenile. 


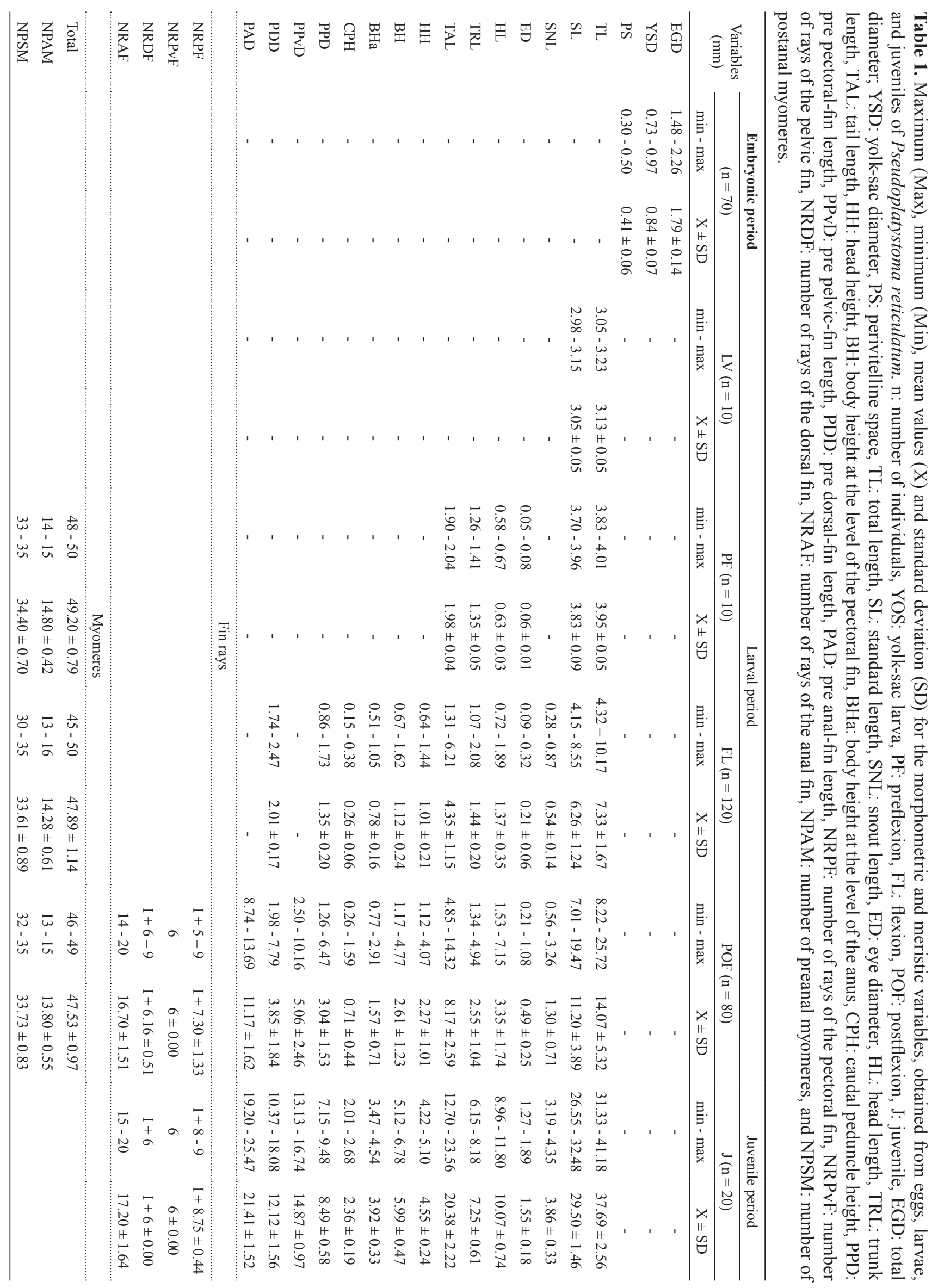


$\mathbf{a}$

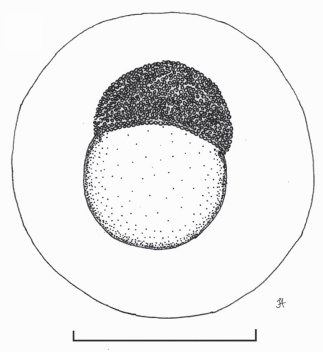

b

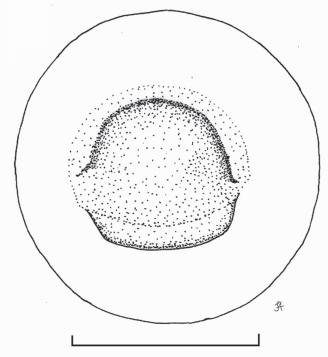

C

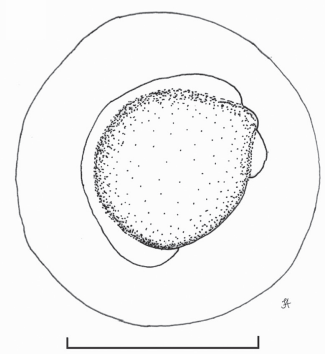

d
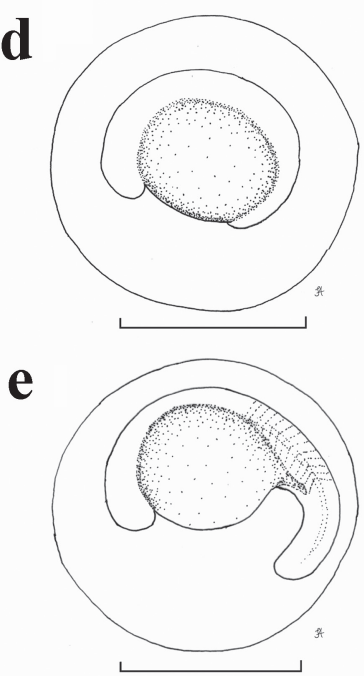

f

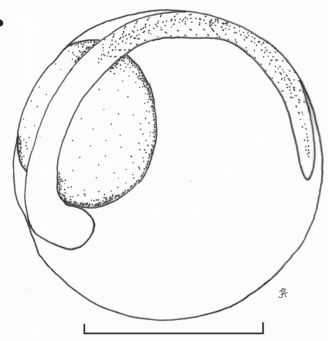

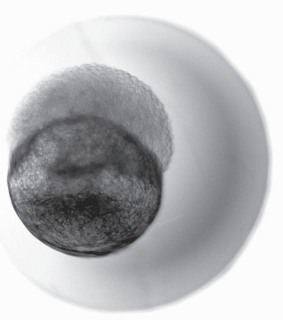
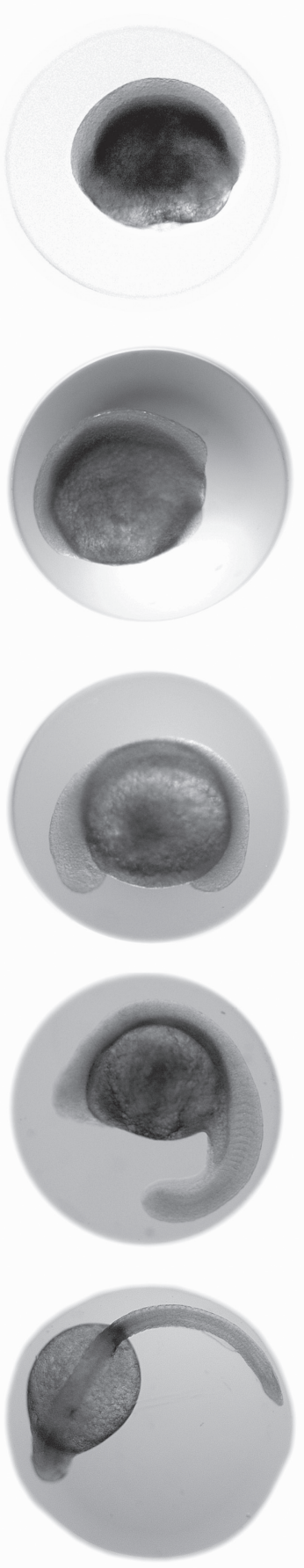

Fig. 3. Drawings and photographs of the embryonic development of Pseudoplatystoma reticulatum. (a) morula, (b) gastrula; (c) initial embryo, (d) tail formation, (e) free tail, and (f) final embryo. Scale $=1 \mathrm{~mm}$.

Postflexion (Fig. 4f-h): This stage began approximately 7 days and $12 \mathrm{~h}$ after hatching, and the total length of larvae varied from 8.22 to $25.72 \mathrm{~mm}$ (mean $\pm \mathrm{SD}=14.07 \pm 5.32$ $\mathrm{mm}$ ). The pigmentation is more intense on the head and along the dorsum, the longitudinal stripe on the lateral side increases, extending from the snout to the operculum. There is the formation of dorsal, anal, adipose, and pelvic fins. At the end of this stage, the pigmentation is characterized by the formation of two longitudinal stripes on the body, one dorsal and the other ventral, united at the caudal peduncle. All fins are pigmented, and the total number of myomeres ranged from 46 to 49 (preanal $=13-15$ and postanal $=32-35)$. The number of fin rays corresponded to: pectoral I+5-9; pelvic 6; dorsal I+6, and anal 14-20 (Table 1).

Juvenile period (Fig. 4i). Twenty specimens were analyzed with total length ranging from 31.33 to $41.18 \mathrm{~mm}$ (mean \pm SD $=37.69 \pm 2.56 \mathrm{~mm}$ ). This period began 21 days and $12 \mathrm{~h}$ after hatching (Fig. 2b). All fins are completely formed and there are no vestiges of the embryonic membrane (finfold). The number of rays of the fins corresponded to: pectoral $\mathrm{I}+8-9$; pelvic 6; dorsal I+6, and anal 15-20 (Table 1). At this period, the pigmentation is maintained and the barbels are also pigmented. Myomeres are not visible.

Analysis of growth. The individuals grew and put on weight as they aged, according to the exponential growth model shown in Fig. 5 a-b. At first, the larvae showed a mean total length of $3.15 \mathrm{~mm}$ and weighed $0.00025 \mathrm{~g}$. Twenty-four days later, they transformed into juveniles, reached a total length of $38.70 \mathrm{~mm}$, and weighed $0.40029 \mathrm{~g}$.

Although growth has increased significantly over time, on the sixth and eighth days, there was a decrease in weight. The marked increase in the size of larvae occurred mainly from 15 days of life on, with an average of $16.70 \mathrm{~mm}$, in the postflexion stage (Fig. 5a). The weight increased markedly from 19 days of life on, with an average of $0.17618 \mathrm{~g}$, when the larvae passed from the postflexion stage to the juvenile period (Fig. 5b).

All morphometric variables related to TL showed discontinuous isometric growth (piecewise linear regression) during development (Table 2). These variables showed higher growth rates after the breakpoint, during the postflexion stage (Fig. $6 \mathrm{a}$-e), at the interval of TL between 12 and $13 \mathrm{~mm}$.

It was not possible to calculate the coefficients of growth for the yolk-sac larva stage, as the head and the trunk could not yet be well delimited. During the preflexion stage (Fig. 7a), the head $(b=0.057)$, trunk $(b=0.250)$, and tail $(b=0.003)$ showed a negative allometric growth. At the flexion stage (Fig. 7b), the head $(b=1.303)$ and the tail $(b=1.386)$ began to show a positive allometric growth, whereas the trunk $(b=0.583)$ maintained a negative allometric growth. At the postflexion stage, (Fig. 7c), the head $(b=1.450)$ and trunk $(b=1.104)$ showed a positive allometric growth and the tail $(b=0.907)$ showed a negative allometry. At the juvenile period (Fig. 7d), the head $(b=0.648)$ and the trunk growth $(b=0.147)$ was allometric negative, whereas the tail growth $(b=1.666)$ was allometric positive. 
a

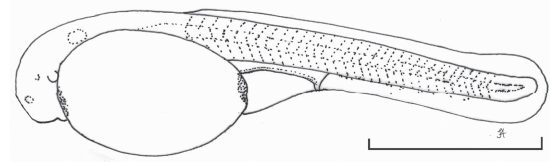

b

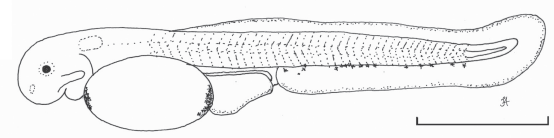

c

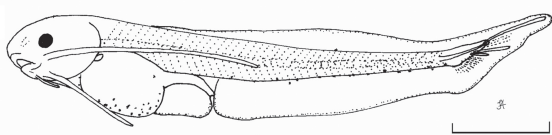

d

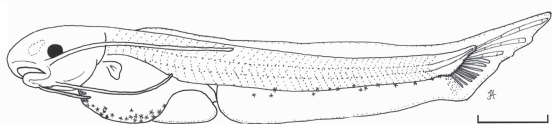

e

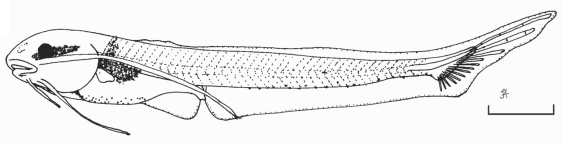

f

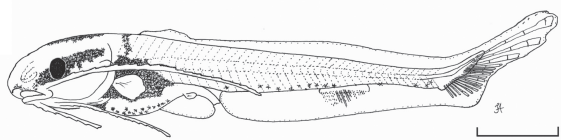

g

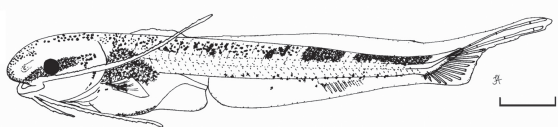

h

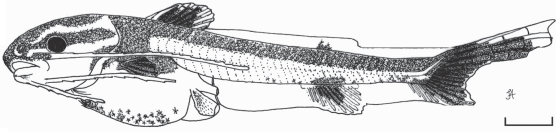

i

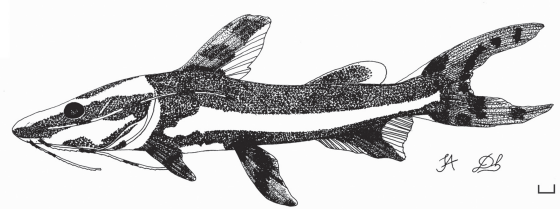

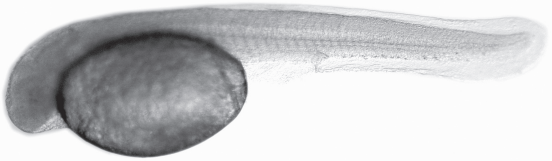
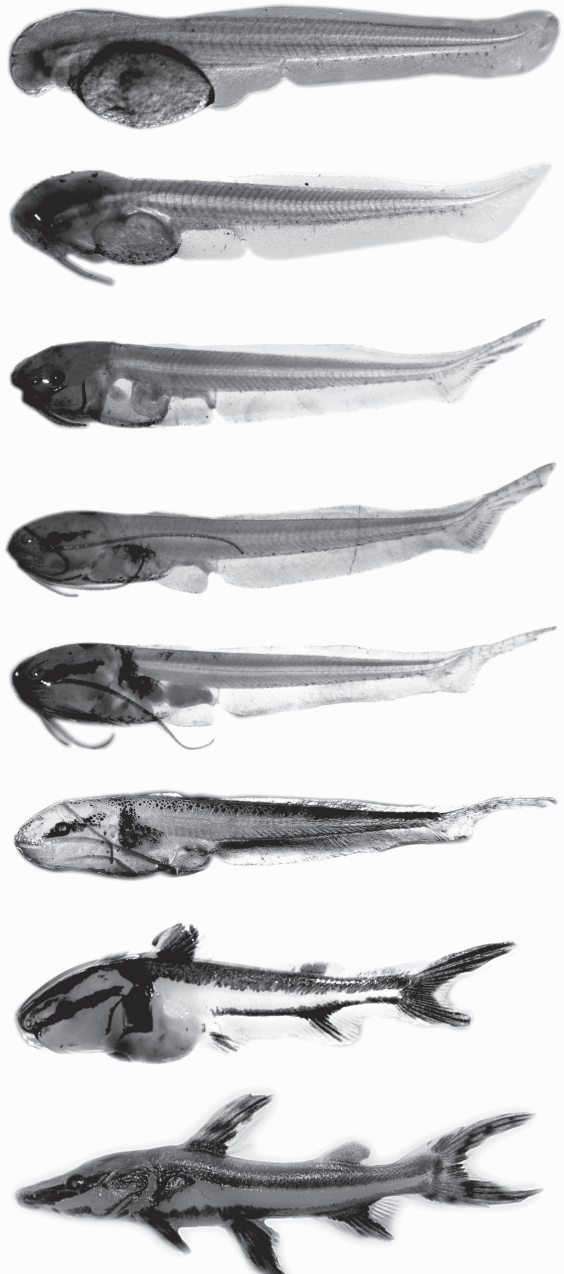

Fig. 4. Drawings and photographs of larvae at different stages and juvenile of Pseudoplatystoma reticulatum: (a) yolk-sac larva (newly-hatched): $\mathrm{TL}=3.05 \mathrm{~mm}$; (b) preflexion: age $=12 \mathrm{~h}, \mathrm{TL}=3.91 \mathrm{~mm}$; (c) early flexion: age $=2$ days, $\mathrm{TL}=5.85 \mathrm{~mm}$; (d) intermediate flexion: age $=4$ days, $\mathrm{TL}=7.91 \mathrm{~mm}$; (e) late flexion: age $=6$ days, $\mathrm{TL}=8.22 \mathrm{~mm}$; (f) early postflexion: age $=7$ days, $\mathrm{TL}=9.23 \mathrm{~mm}$; $(\mathrm{g})$ intermediate postflexion: age $=8$ days, $\mathrm{TL}=10.38 \mathrm{~mm}$; (h) late postflexion: age $=10$ days, $\mathrm{TL}$ $=9.55 \mathrm{~mm}$; and (i) juvenile: age $=21$ days, $\mathrm{TL}=36.42 \mathrm{~mm}$. Scale $=1 \mathrm{~mm}$.

a

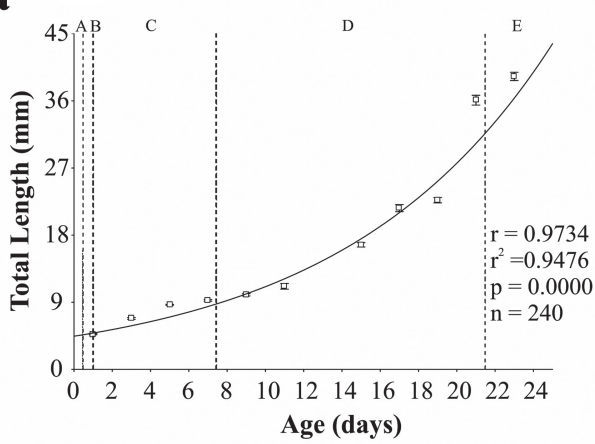

b

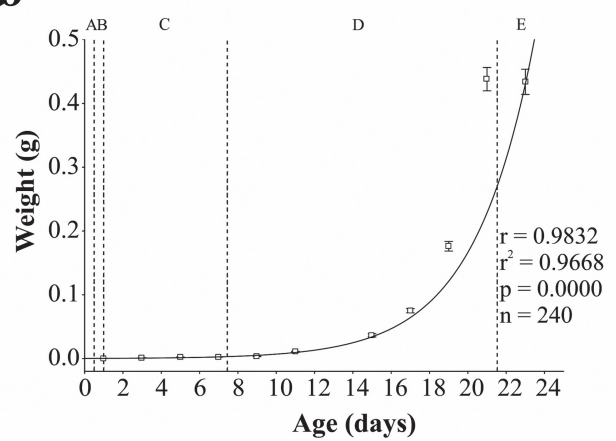

Fig. 5. Pseudoplatystoma reticulatum growth during larval and juvenile development, from hatching to the $24^{\text {th }}$ day of life. Larval stages: A: yolk-sac larva, $\mathrm{B}=$ preflexion, $\mathrm{C}=$ flexion, and $\mathrm{D}=$ postflexion; and $\mathrm{E}=$ juvenile. (a) Relationship between total length and age, and (b) relationship between weight and age. 
Table 2. Values of the linear (L), quadratic (Q) and piecewise linear (S) regression analysis of the morphometric variables obtained relative to the total length of the larvae and juveniles of Pseudoplatystoma reticulatum. $\mathbf{R}^{2}=$ coefficient of determination, $\mathbf{B M}=$ best model, $\mathbf{B P}=$ breakpoint $(\mathrm{mm})$, $\mathbf{a}$ and $\mathbf{b}=$ regression parameters ( $\mathrm{a}$, slope coefficient; $\mathbf{b}$, linear coefficient), $\mathbf{N}=$ number of individuals analyzed, $\mathbf{E D}=$ eye diameter, $\mathbf{H H}=$ head height, $\mathbf{B H}=$ body height, $\mathbf{B H a}=$ body height at the level of the anus, $\mathbf{C P H}=$ caudal peduncle height. $(*)=\mathrm{p}<0.05$, bold $=$ values of the significant regressions.

\begin{tabular}{|c|c|c|c|c|c|c|c|c|c|c|c|c|c|}
\hline \multirow{2}{*}{ Relation } & \multicolumn{3}{|c|}{$\mathrm{R}^{2}$} & \multicolumn{3}{|c|}{ F Test } & \multirow{2}{*}{$\mathrm{BM}$} & \multirow{2}{*}{$\mathrm{BP}$} & \multirow{2}{*}{ a1 } & \multirow{2}{*}{ b1 } & \multirow{2}{*}{$\mathrm{a} 2$} & \multirow{2}{*}{ b2 } & \multirow{2}{*}{$\mathrm{N}$} \\
\hline & $\mathrm{L}$ & Q & S & $\mathrm{Q} / \mathrm{L}$ & $\mathrm{S} / \mathrm{Q}$ & $\mathrm{S} / \mathrm{L}$ & & & & & & & \\
\hline $\mathrm{ED} / \mathrm{TL}$ & 0.98 & 0.98 & 0.98 & $6.64 *$ & $17.56^{*}$ & $12.33 *$ & S & 0.41 & 0.03 & -0.04 & 0.04 & -0.12 & 240 \\
\hline $\mathrm{HH} / \mathrm{TL}$ & 0.92 & 0.97 & 0.97 & $396.19 *$ & $10.50 *$ & $211.67 *$ & S & 1.77 & 0.13 & 0.10 & 0.08 & 1.62 & 230 \\
\hline $\mathrm{BH} / \mathrm{TL}$ & 0.94 & 0.96 & 0.97 & $192.99 *$ & $40.13 *$ & $134.04 *$ & S & 2.11 & 0.14 & 0.05 & 0.12 & 1.45 & 220 \\
\hline $\mathrm{BHa} / \mathrm{TL}$ & 0.96 & 0.97 & 0.98 & $81.49^{*}$ & $27.32 *$ & $59.37 *$ & S & 1.36 & 0.09 & 0.10 & 0.09 & 0.60 & 220 \\
\hline $\mathrm{CPH} / \mathrm{TL}$ & 0.97 & 0.97 & 0.98 & $5.38 *$ & $91.64 *$ & $49.64 *$ & S & 0.61 & 0.04 & -0.05 & 0.06 & -0.08 & 220 \\
\hline
\end{tabular}
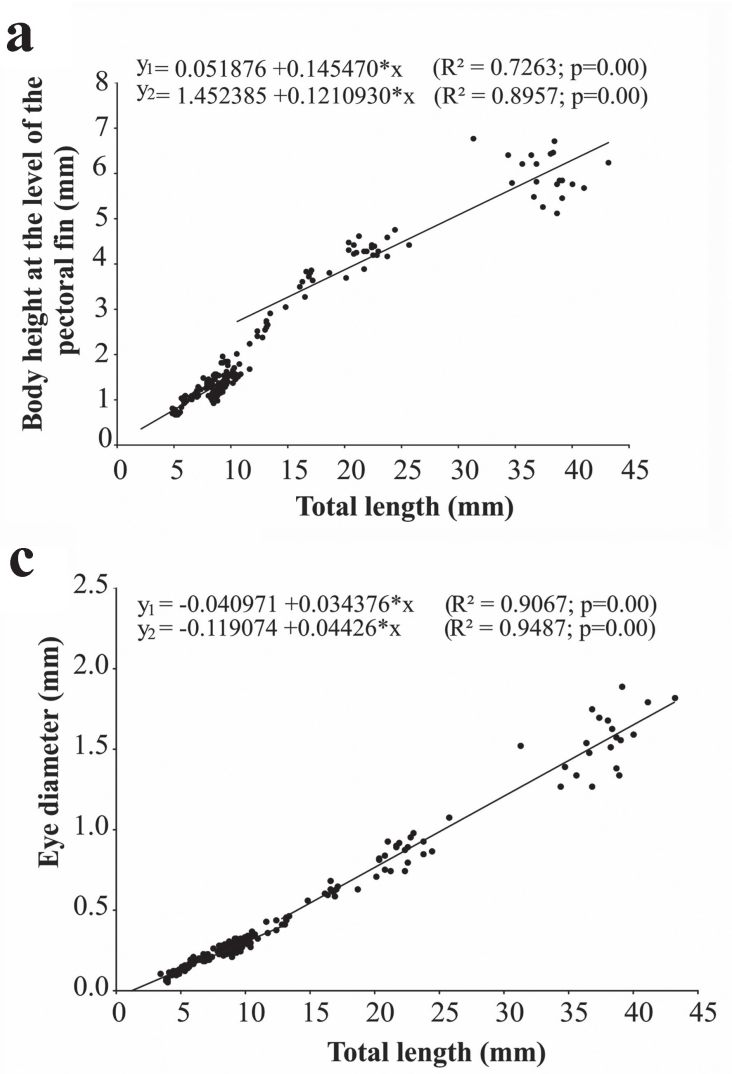

b

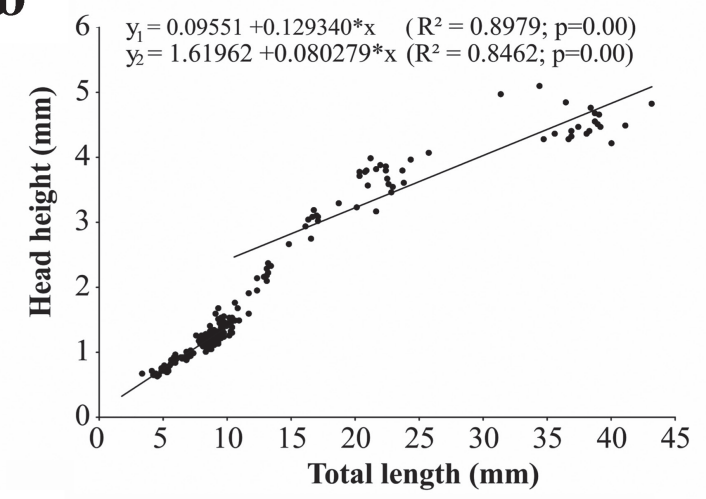

d

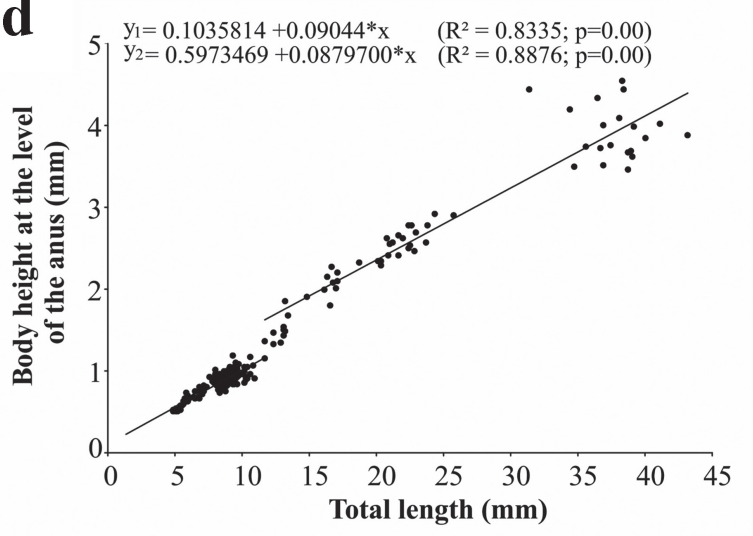

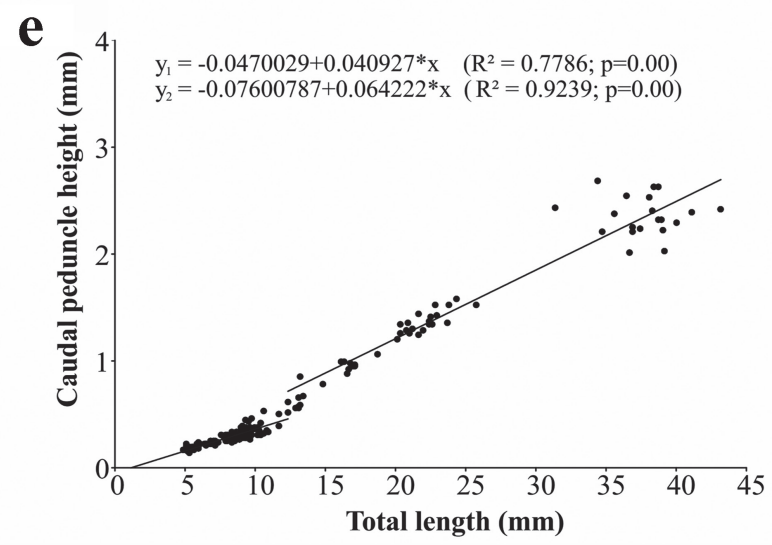

Fig. 6. Allometric growth of the body parts in relation to the total length during the development of Pseudoplatystoma reticulatum. 

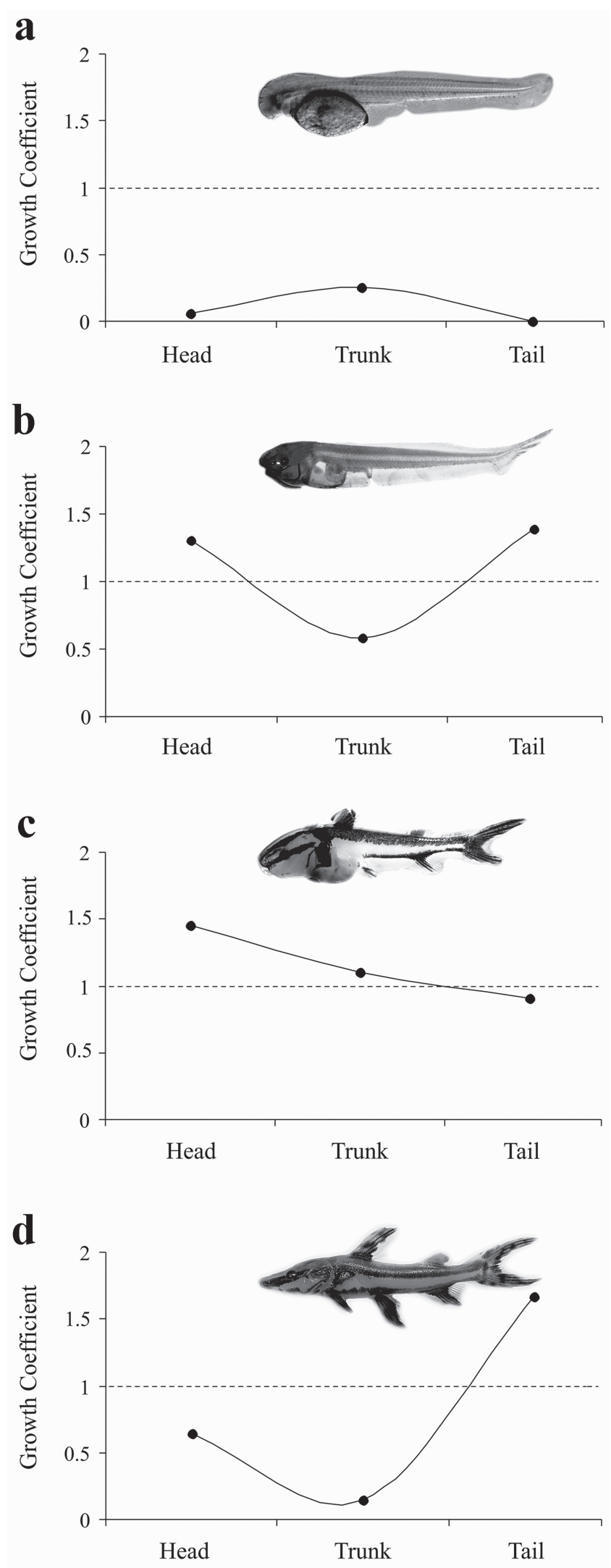

Fig. 7. Growth coefficients of the head, trunk, and tail during the development of Pseudoplatystoma reticulatum. Larvae in preflexion (a), flexion (b), and postflexion (c) stages; and juvenile (d).

\section{Discussion}

The characteristics of embryonic development in $P$. reticulatum are similar to those of most freshwater teleosts, in terms of segmentation, development stages, and hatching (Castellani et al., 1994; Ribeiro et al., 1995; Nakatani et al., 2001). The eggs showed a broad perivitelline space, which, according to Nakatani et al. (2001), means that it occupies from 20 to $29.9 \%$ of the total volume of the egg. This may be an adaptation to improve embryo survival by protecting it against damage (Andrade-Talmelli et al., 2001; Sanches et al., 2001). This characteristic is common among migratory species that spawn in lotic environments, such as Salminus brasiliensis (Cuvier, 1816) (Nakatani et al., 2001), Brycon orbignyanus (Valenciennes, 1850) (ReynalteTataje et al., 2004), Pseudoplatystoma corruscans (Spix \& Agassiz, 1829) (Nakatani et al., 2001), and Hemisorubim platyrhynchos (Valenciennes, 1840) (Andrade et al., 2014).

Pérez et al. (2001) reported for Pseudoplatystoma fasciatum (Linnaeus 1766), at an average temperature of $25.5^{\circ} \mathrm{C}$, the morula stage with $2 \mathrm{~h} 15 \mathrm{~min}$, the gastrula stage at the fourth hour of incubation, and embryo differentiation starting at the seventh hour of incubation. These results are similar to those obtained in the present study, except for embryo differentiation, which occurred 6 $\mathrm{h}$ after fecundation. This difference may result from higher temperatures that accelerate the development. The rapid embryonic development (14 $\mathrm{h}$ at an average temperature of $28.2^{\circ} \mathrm{C}$ ) of $P$. reticulatum in the present study can also be observed in species using the same reproductive strategy (long-distance migratory species). This rapid embryonic development may allow longer survival, as the species does not have parental care (Oliveira et al., 2012). Pérez et al. (2001) reported $14 \mathrm{~h}$ of incubation at a temperature of $27^{\circ} \mathrm{C}$, corroborating the present study. The embryonic period of species using different reproductive strategies can be much longer. For example, the embryonic period of Rhamdia quelen (Quoy \& Gaimard, 1824) lasted 30 h 5 min at $24{ }^{\circ} \mathrm{C}$ (Pereira et al., 2006), and that of Parauchenipterus galeatus (Linnaeus, 1766), lasted $64 \mathrm{~h}$ at a water temperature of 27$28^{\circ} \mathrm{C}$ (Sanches et al., 1999).

The larvae of $P$. reticulatum have characteristic of altricial species, i.e., larvae hatching are poorly developed. They have small size at hatching: the mean standard length in newly-hatched larvae is $3.05 \pm 0.05 \mathrm{~mm}$. Pérez et al. (2001) obtained a very similar result for $P$. fasciatum, 3.01 $\pm 0.12 \mathrm{~mm}$. However, this species is relatively larger than some Siluriformes, such as Pseudoplatystoma corruscans (Spix \& Agassiz, 1829), with $2.69 \pm 0.01 \mathrm{~mm}$ (Landines et al., 2003) and $2.51 \mathrm{~mm}$ (Nakatani et al., 2001); Pimelodus maculatus Lacepède, 1803, with $2.56 \pm 0.13 \mathrm{~mm}$ (Luz et al., 2001); and R. quelen, with $2.76 \mathrm{~mm}$ (Amorim et al., 2009). However, they are smaller than Rhinelepis aspera Spix \& Agassiz, 1829, which achieved $3.44 \pm 0.08 \mathrm{~mm}$ (Perine et al., 2009). Furthermore, the larvae of $P$. reticulatum hatch with non-pigmented eyes and non-functional mouth 
and intestine. These characteristics are common to other species, such as $P$. corruscans (Marques et al., 2008) and P. maculatus (Luz et al., 2001). According to Lasker et al. (1970), eye pigmentation and mouth opening are events that occur simultaneously and are directly related to exogenous feeding. Luz et al. (2001) associate these events with the beginning of the horizontal swimming movements of the larvae.

On the first days of life, the larvae depend on their endogenous reserves for feeding. According to Luz et al. (2001), the time for reserve reabsorption is related to water temperature, and may be associated with the amount of yolk, and, therefore, the type of reproductive strategy adopted by the parents. In the present study, we observed that, 48 $\mathrm{h}$ after hatching at an average temperature of $27.5^{\circ} \mathrm{C}$, the larvae of $P$. reticulatum at flexion stage began the transition from endogenous to exogenous feeding. Four days later, still at the flexion stage, the yolk sac was completely absorbed and the exogenous feeding became exclusive. According to Kamler (1992), this transition from endogenous to exogenous feeding is considered a critical phase, as the larva needs to find suitable food for its survival before the depletion of the reserves. Pérez et al. (2001) reported that on the fourth day, the endogenous reserves of $P$. fasciatum depleted completely.

We also observed a cannibalism behavior. According to Hecht \& Pienaar (1993), the cannibalism occurs in a population in situations of food scarcity, high stocking densities, and lack of shelter and light and dark conditions. This behavior occurs in several fish species, but is more common in carnivorous fish and at early stages of development (Atencio-García \& Zaniboni Filho, 2006). Luz et al. (2001) and Luz \& Zaniboni Filho (2001) also observed a cannibalism behavior in $P$. maculatus larvae.

When $P$. reticulatum larvae hatch, they are transparent, with nearly no pigmentation and a concentration of chromatophores in the anterior and posterior regions of the yolk sac. This characteristic seems to be present in several species of the Pimelodidae family (i.e. H. plathyrhynchos, P. maculatus, P. corruscans, Sorubim cf. lima), and it is difficult to differentiate them at this stage of development when they occur in the same river basin. During development, the larvae acquire a characteristic pigmentation until they reach the juvenile phase. It is important to note that this pigmentation is very similar to that of $P$. corruscans larvae and juveniles (Nakatani et al., 2001). According to Kossowski \& Madrid (1991), the initial pigmentation pattern is kept for approximately two months and a half until the individual acquires its definitive pigmentation pattern.

The total or partial number of myomeres is considered an important variable for the identification of fish larvae (Snyder, 1979). According to Cavicchioli et al. (1997), at preflexion and flexion stages, this is an important characteristic to differentiate species. In the present study, the number of myomeres of $P$. reticulatum varied from 45 to 50 (preanal $=13-16$ and postanal $=30-35)$, similar to the number of myomeres found by Pérez et al. (2001) for $P$. fasciatum, which varied from 45 to 47 . For $P$. corruscans, the number of myomeres also varied from 45 to 47 (preanal $=12-14$ and postanal $=32-35)($ Nakatani $e t$ al., 2001). Therefore, the number of myomeres is not the most appropriate variable to distinguish the larvae of these species in case they occur in the same river basin.

In general, larval growth increased significantly over time. However, on the sixth and eighth days, there was a decrease in weight. This period corresponds to the end of the flexion stage and the beginning of the postflexion stage, when the complete absorption of the yolk sac occurs. According to Landines et al. (2003), at this stage the larva can face difficulties to obtain its first food; it is a critical stage in the larviculture of carnivore species. However, the increase in length growth rate was remarkably evident from the $18^{\text {th }}$ day on, and the growth in weight from the $19^{\text {th }}$ day on, when the larvae were at the postflexion stage. At this stage, the fish already concluded the development of priority body parts for the larval stages (Fuiman, 1983). According to Durand \& Loubens (1969), modifications in the bone structure influence growth in length, whereas physiological modifications can alter fish weight at some point.

Larval metamorphosis is the result of a sequence of stable stages that are interrupted by a change in development (Balon, 1984). These changes result from an abrupt growth in the relationships between body variables. The inflection points for all variables in $P$. reticulatum occurred during the postflexion stage, in the interval between 12 and $13 \mathrm{~mm}$ of total length, a period when the larvae have recently passed through the critical phase of the mixed feeding. According to Kovác et al. (1999), after this interval of the total length the larva will undergo expressive body modifications, which may be associated with some changes, i.e. foraging habitats.

Changes in body shape and, consequently, in the functional development occur rapidly during the beginning of the development stages (Peña \& Dumas, 2009). The allometric growth during the early larval development was observed in different teleost groups (Osse \& Boogaart, 2004). It was considered an adaptive response to neutralize environmental pressures, increasing the survival and growth probability during the early development. The allometric growth alters the body shape due to differential growth (Fuiman, 1983) of organs and systems involved in basic functions (i.e.: feeding, breathing, and movement) in detriment of organs that have a lower priority for survival (Osse \& Boogaart, 1995). The relationships of allometric growth in $P$. reticulatum showed differential growth of body parts during development stages. At the flexion stage, the head and the tail showed a positive allometric growth, which occurs due to a priority need for growing to maximize feeding (which begins at the end of this stage) and swimming to escape predators and capture preys, reduce energy cost during movement, and continue the development of the respiratory and nervous systems 
(Fuiman, 1983; Osse \& Boogaart, 1995; Snik et al., 1997; Gisbert, 1999). At the postflexion stage, the trunk begins to show a positive allometric growth, when the other systems begin to develop themselves.

In conclusion, embryonic development is fast in $P$. reticulatum, the morphologic characteristics of newly hatched larvae are similar to those of other migratory species (e.g. P. corrruscans, P. maculatus) (Nakatani et al., 2001), and this species grows considerably during development (Fig. 2a-b). At first, there is a differential growth of the head and tail, and a marked growth of the trunk, which changes the ontogenetic priorities for the abilities of feeding, swimming, and breathing. This period of transition from endogenous to exogenous feeding is critical for larval survival. At this time, the larvae need to adapt to new life conditions and get suitable food for survival before yolk-sac depletion. Most morphological changes during larval development occur at the final stages. The information obtained in the present study is very important for understanding the species ecology, systematics, and breeding, in particular concerning ontogenetic variation in morphology, growth, feeding, behavior, and mortality. Our results confirmed the hypothesis of differentiated growth patterns for priority functions during early ontogeny of this species.

\section{References}

Ahlstrom, E. H. \& O. P. Ball. 1954. Description of eggs and larvae of jack mackerel (Trachurus symmetricus) and distribution and abundance of larvae in 1950 and 1951. Fishery Bulletin, 56: 209-245.

Amorim, M. P., B. V. C. Gomes, Y. S. Martins, Y. Sato, E. Rizzo \& N. Bazzoli. 2009. Early development of the silver catfish Rhamdia quelen (Quoy \& Gaimard, 1824) (Pisces: Heptapteridae) from the São Francisco River Basin, Brazil. Aquaculture Research, 40: 172-180.

Andrade, F. F., M. C. Makrakis, A. F. Lima, L. Assumpção, S. Makrakis \& S. F. R. Pini. 2014. Desenvolvimento embrionário, larval e juvenil de Hemisorubim platyrhynchos (Siluriformes, Pimelodidae) da bacia do rio Paraná. Iheringia, Série Zoologia, 104: 70-80.

Andrade-Talmelli, E. F., E. T. Kavamoto, E. Romagosa \& N. Fenerich-Verani. 2001. Embryonic and larval development of the "piabanha", Brycon insignis, Steindachner, 1876 (Pisces, Characidae). Boletim do Instituto de Pesca, 27: 21-28.

Atencio-García, V. \& E. Zaniboni Filho. 2006. El canibalismo en la larvicultura de peces. Revista MVZ Córdoba, 11: 9-19.

Balon, E. K. 1984. Reflections on some decisive events in the early life of fishes. Transactions of the American Fisheries Society, 113: $178-185$.

Benitez, H. O. M., J. A. R. Pulido \& C. R. O. Zapata. 2003. El bagre rayado (Pseudoplatystoma fasciatum). Manual de reproducción y cultivo. Ministerio de Agricultura y Desarrollo Rural Regional Oriental. INPA Instituto Nacional de Pesca y Acuicultura. Imagen \& Publicidad, Villa Vicencio, Colombia.
Castellani, L. R., H. G. Tse, H. S. L. Santos, R. H. S. Faria \& M. L. S. Santos. 1994. Desenvolvimento embrionário do curimbatá Prochilodus lineatus (Valenciennes, 1836) (Cypriniformes, Prochilodontidae). Brazilian Journal of Morphological Sciences, 11: 99-105.

Castro, D. 1986. Los bagres de la subfamilia Sorubiminae de la Orinoquia y Amazonas Colombiana (Siluriformes: Pimelodidae). Boletin Ecotrópica, 13: 1-14.

Cavicchioli, M., K. Nakatani \& O. A. Shibatta. 1997. Morphometric variation of larvae and juveniles of the piranhas Serrasalmus spilopleura and S. marginatus (Characidae: Serrasalminae) of the Paraná basin, Brazil. Ichthyological Exploration of Freshwaters, 8: 97-106.

Crepaldi, D. V., E. A. Teixeira, P. M. Faria, L. P. Ribeiro, D. C. Melo, D. A. A. Oliveira, E. M. Turra \& B. M. Queiroz. 2008. Rendimento de carcaça em surubim (Pseudoplatystoma spp.) avaliado por ultra-som. Revista Brasileira de Saúde e Produção Animal, 9: 813-824.

Durand, J. R. \& G. Loubens. 1969. Croissance en longueur d'Alestes baremoze (Joannis 1835) (Poissons, Characidae) dans le Bas Chari et le lac Tchad. Cahiers ORSTOM, Série Hydrobiologique, 3: 59-105.

Fuiman, L. A. 1983. Growth gradients in fish larvae. Journal of Fish Biology, 23: 117-123.

Gisbert, E. 1999. Early development and allometric growth patterns in Siberian sturgeon and their ecological significance. Journal of Fish Biology, 54: 852-862.

Hecht, T. \& A. G. Pienaar. 1993. A review of cannibalism and its implications in fish larviculture. Journal of the World Aquaculture Society, 24: 246-261.

Heming, T. A. \& R. K. Buddington. 1988. Yolk absorption in embryonic and larval fishes. Pp. 407-446. In: Randall, D. J. \& W. S. Hoar (Eds.). Fish Physiology. New York, Academic Press.

Kamler, E. 1992. Early life history of fish: an energetics approach. London, Chapman \& Hall, 267p.

Kossowski, C. \& F. Madrid. 1991. Observaciones de los estadios embrionario y larval del bagre rayado cabezón Pseudoplatystoma fasciatum (Linnaeus, 1766) (Pisces, Siluriformes). BioLlania, 8: 9-15.

Kováč, V., G. H. Copp \& M. P. Francis. 1999. Morphometry of the stone loach, Barbatula barbatula: do mensural characters reflect the species' life history thresholds?. Environmental Biology of Fishes, 56: 105-115.

Landines, M. A., J. A. Senhorini, A. I. Sanabria \& E. C. Urbinati. 2003. Desenvolvimento embrionário do pintado (Pseudoplatystoma coruscans Agassiz, 1829). Boletim Técnico do CEPTA, 16: 1-13.

Lasker, R., H. M. Feder, G. H. Theilacker \& R. C. May. 1970. Feeding, growth, and survival of Engraulis mordax larvae reared in the laboratory. Marine Biology, 5: 345-353.

Leonardo, A. F. G., E. Romagosa, M. I. Borella \& S. R. Batlouni. 2004. Induced spawning of hatchery-raised Brazilian catfish, cachara Pseudoplatystoma fasciatum (Linnaeus, 1766). Aquaculture, 240: 451-461.

Lopes, T. M., F. G. Oliveira, A. Bialetzki \& A. A. Agostinho. 2015. Early development in the mouth-brooding cichlid fish 
Satanoperca pappaterra (Perciformes: Cichlidae). Revista de Biología Tropical, 63: 139-153.

Luz, R. K., D. A. Reynalte-Tataje, A. A. Ferreira \& E. Zaniboni Filho. 2001. Desenvolvimento embrionário e estágios larvais do mandi-amarelo Pimelodus maculatus. Boletim do Instituto de Pesca, 27: 49-55.

Luz, R. K. \& E. Zaniboni Filho. 2001. Utilização de diferentes dietas na primeira alimentação do mandi amarelo (Pimelodus maculatus, Lacépède). Acta Scientiarum, Biological Sciences, 23: 483-489.

Marques, C., L. S. O. Nakaghi, F. Faustino, L. N. Ganeco \& J. A. Senhorini. 2008. Observation of the embryonic development in Pseudoplatystoma coruscans (Siluriformes: Pimelodidae) under light and scanning electron microscopy. Zygote, 16: 333-342.

Nakatani, K., A. A. Agostinho, A. Bialetzki, G. Baumgartner, P. V. Sanches, M. C. Makrakis \& C. S. Pavanelli. 2001. Ovos e larvas de peixes de água doce: desenvolvimento e manual de identificação. Maringá, Eduem, 378p.

Oliveira, F. G., A. Bialetzki, L. C. Gomes, M. Santin \& T. L. Taguti. 2012. Desenvolvimento larval de Brycon hilarii (Characiformes, Characidae). Iheringia, Série Zoologia, 102: 62-70.

Osse, J. W. M. \& J. G. M. van den Boogaart. 1995. Fish larvae, development, allometric growth, and the aquatic environment. ICES Marine Science Symposia, 201: 21-34.

Osse, J. W. M. \& J. G. M. van den Boogaart. 2004. Allometric growth in fish larvae: timing and function. Pp. 167-194. In: Govoni, J. J. (Ed.). Development of form and function in fishes and the question of larval adaptation. Bethesda, Maryland, The American Fisheries Society, Symposium 40.

Peña, R. \& S. Dumas. 2009. Development and allometric growth patterns during early larval stages of the spotted sand bass Paralabrax maculatofasciatus (Percoidei: Serranidae). Journal of Fish Biology, 67: 640-651.

Pereira, C. R., L. J. G. Barcellos, L. C. Kreutz, R. M. Quevedo, F. Ritter \& L. B. Silva. 2006. Embryonic and larval development of jundiá (Rhamdia quelen, Quoy \& Gaimard, 1824, Pisces, Teleostei), a South American catfish. Brazilian Journal of Biology, 66: 1057-1063.

Pérez, P. P. P., F. A. Bocanegra \& R. I. Orbe. 2001. Reproducción inducida de la doncella Pseudoplatystoma fasciatum y desarrollo embrionario-larval. Folia Amazónica, 12: 141154.

Perine, V. R., Y. Sato, E. Rizzo \& N. Bazzoli. 2009. Biology of eggs, embryos and larvae of Rhinelepis aspera (Spix \& Agassiz, 1829) (Pisces: Siluriformes). Zygote, 18: 159-171.

Reid, S. L. 1983. La biología de los bagres rayados Pseudoplatystoma fasciatum y P. tigrinum en la cuenca del río Apure, Venezuela. Revista Unellez de Ciencia y Tecnología, 1: 13-41.

Resende, E. K. 2003. Migratory fishes of the Paraguay-Paraná Basin excluding the Upper Paraná River. Pp. 99-155. In: Carolsfeld, J., B. Harvey, C. Ross \& A. Baer (Eds.). Migratory fishes of South America: Biology, Fisheries and Conservation Status. Victoria, World Bank.
Resende, E. K., A. C. Catella, F. L. Nascimento, S. S. Palmeira \& V. L. L. Almeida. 1995. Biologia do curimbatá (Prochilodus lineatus), pintado (Pseudoplatystoma corruscans) e cachara (Pseudoplatystoma fasciatum) na bacia hidrográfica do rio Miranda, Pantanal do Mato Grosso do Sul, Brasil. EMBRAPA - CPAP, Corumbá, MS. EMBRAPA - CPAP. Boletim de Pesquisa, 02. 75p.

Resende, E. K., R. A. C. Pereira, V. L. L. Almeida \& A. G. Silva. 1996. Alimentação de peixes carnívoros da planície inundável do rio Miranda, Pantanal, Mato Grosso do Sul, Brasil. EMBRAPA-CPAP, Corumbá, MS. EMBRAPA - CPAP. Boletim de Pesquisa, 03. 36p.

Reynalte-Tataje, D., E. Zaniboni Filho \& J. R. Esquivel. 2004. Embryonic and larvae development of piracanjuba, Brycon orbignyanus Valenciennes, 1849 (Pisces, Characidae). Acta Scientiarum, Biological Sciences, 26: 67-71.

Ribeiro, C. R., H. S. Leme dos Santos, \& A. A. Bolzan. 1995. Estudo comparativo da embriogênese de peixes ósseos (Pacu, Piaractus mesopotamicus; Tambaqui Calossoma macropomum e híbrido Tambacu). Brazilian Journal of Biology, 55: 65-78.

Romagosa, E. 2006. Biologia reprodutiva e fisiologia de peixes em confinamento: o cachara, Pseudoplatystoma fasciatum como modelo. Pp.107-116. In: Cyrino, J. E. P. \& E. C. Urbinati (Eds.). Tópicos Especiais em Biologia Aquática e Aquicultura: Palestras. AQUACIÊNCIA 2004: Vitória. Eds: Sociedade Brasileira de Aqüicultura e Biologia Aquática, Jaboticabal, SP.

Romagosa, E. 2010. Reproductive status in females of the Brazilian catfish, Pseudoplatystoma fasciatum reared in cages. Journal of Applied Ichthyology, 26: 806-811.

Romagosa, E., P. Paiva, E. F. Andrade-Talmelli \& H. M. Godinho. 2004. Biologia reprodutiva de fêmeas de cachara, Pseudoplatystoma fasciatum (Teleostei, Siluriformes, Pimelodidae), mantidas em cativeiro. Boletim do Instituto de Pesca, 29: 151-159.

Romagosa, E., S. R. Batlouni, M. I. Borella \& A. F. G. Leonardo. 2005. Involução dos folículos pós-ovulatórios em Pseudoplatystoma fasciatum (Pisces, Teleostei). Boletim do Instituto de Pesca, 31: 129-135.

Sanches, P. V., K. Nakatani \& A. Bialetzki. 1999. Morphological description of the developmental stages of Parauchenipterus galeatus (Linnaeus, 1766) (Siluriformes, Auchenipteridae) on the floodplain of the upper Paraná River. Revista Brasileira de Biologia, 59: 429-438.

Sanches, P. V., G. Baumgartner, A. Bialetzki, M. R. Suiberto, F. D. C. Gomes, K. Nakatani \& N. D. C. Barbosa. 2001. Caracterização do desenvolvimento inicial de Leporinus friderici (Osteichthyes, Anostomidae) da bacia do rio Paraná, Brasil. Acta Scientiarum, Biological Sciences, 23: 383-389.

Snik, G. M. J. van, J. G. M. van den Boogaart \& J. W. M. Osse. 1997. Larval growth patterns in Cyprinus carpio and Clarias gariepinus with attention to the finfold. Journal of Fish Biology, 50: 1339-1352.

Snyder, D. E. 1979. Myomere and vertebrae counts of the North America cyprinids and catostomids. Pp. 53-69. In: Hoyt, R. D. (Ed.). Proceedings of Third Symposium on Larval Fish. Western Kentucky University, Bowling Gree. 
Sokal, R. R. \& F. J. Rohlf. 1981. Biometry. The principles and practice of statistics in biological research. New York, W. H. Freenan and Company.

Streit Júnior, D. P., R. N. Sirol, R. P. Ribeiro, M. Digmayer, J. M. Galo, G. V. Moraes \& J. A Povh. 2012. Parâmetros seminais de reprodutores de Pseudoplatystoma reticulatum, em cativeiro, pré e pós-indução hormonal. Revista Brasileira de Reprodução Animal, 36: 188-193. 